A PostScript Cookbook 
Other books of related interest from Macmillan Education

Easily into dBASE III Jim Gilligan

dBASE III and III PLUS - A Troubleshooting Guide Elizabeth Lynch

Word Processing with Amstrad: The PCW8256/8512

Ron Hughes

Using $C P / M$

Peter Gosling

Sorting Routines for Microcomputers

Keith McLuckie and Angus Barber

Geometric and Artistic Graphics: Design Generation with

Microcomputers

Jean-Paul Delahaye

Advanced Graphics with the IBM Personal Computer

Ian O. Angell

Advanced BASIC Scientific Subroutines

B. V. Cordingley and D. J. Chamund

The Computer Handbook: A Businessman's Guide to Choosing and Using Computer Systems

Charles Jones

Understanding Management Software

Andrew Leigh 


\section{A PostScript Cookbook}

Barry Thomas

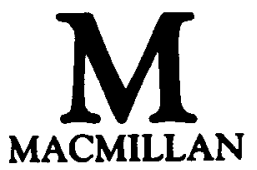


(C) Barry Thomas 1988

All rights reserved. No reproduction, copy or transmission of this publication may be made without written permission.

No paragraph of this publication may be reproduced, copied or transmitted save with written permission or in accordance with the provisions of the Copyright Act 1956 (as amended), or under the terms of any licence permitting limited copying issued by the Copyright Licensing Agency, 33 - 4 Alfred Place, London WC1E 7DP.

Any person who does any unauthorised act in relation to this publication may be liable to criminal prosecution and civil claims for damages.

First published 1988

Published by

MACMILLAN EDUCATION LTD

Houndmills, Basingstoke, Hampshire RG21 2XS

and London

Companies and representatives

throughout the world

Compaq is a trademark of Compaq Computer Systems

IBM is a registered trademark of International Business Machines Incorporated

Linotronic 300 is a registered trademark of Allied Corporation

Macintosh is a trademark of Apple Computer Incorporated

PostSCRIPT is a trademark of Adobe Systems Incorporated

Times and Helvetica are registered trademarks of Allied Corporation

Ventura Publisher is a trademark of Ventura Software Incorporated

WordStar is a registered trademark of MicroPro International Corporation

British Library Cataloguing in Publication Data

Thomas, Barry, 1958 -

A PostSCRIPT cookbook.

1. Microcomputer systems. Programming

languages; PosTSCRIPT

I. Title

$005.2^{\prime} 6$

ISBN 978-0-333-48478-4 ISBN 978-1-349-10642-4 (eBook)

DOI 10.1007/978-1-349-10642-4 


\section{CONTENTS}

PREFACE, vii

1. ALL ABOUT POSTSCRIPT, 1 WHAT IS POSTSCRIPT?, 1 POSTSCRIPT LOOKALIKES, 2 THE LANGUAGE, 2

The Stack

Postfix Notation

User Procedures

USER AND DEVICE SPACE, 4

PATHS, 4

POSTSCRIPT PROGRAMS, 4

Program Comments

Program Structure

2. USING TEXT, 7

SIMPLE TEXT, 9

GRAY, OUTLINE AND CLIPPED TEXT, 13

LEFT ALIGNED TEXT, 17

JUSTIFIED TEXT, 21

CIRCULAR TEXT, 26

CHARACTER TRANSFORMATIONS, 29

3. USING GRAPHICS, 33

PLAIN PAGE FRAME, 34

FADED PAGE FRAME, 36

POLYGON, 39

STACKED BAR CHART, 42

BAR CHART, 46

PIE CHART, 50

USING CURVETO, 55 
CURVETO PATTERN, 56

BITMAPPED GRAPHICS, 58

Mask Graphics

Grey Scale Bit Graphics

4. BUILDING A NEW FONT, 63

BUYING FONTS, 63

BUILDING FONTS, 64

A NEW FONT, 65

5. THE OPERATORS, 71

SYNTAX, 71

OPERATORS, 71

OPERANDS, 72

THE OPERATORS, 73

\section{APPENDICES}

A. POSTSCRIPT TYPESETTING, 133

POSTSCRIPT FILE CONVENTIONS, 133

TYPESETTER OUTPUT, 134

B. EXECUTIVE MODE, 137

STARTING EXECUTIVE, 137

ERRORS, 139

RECURSIVE EXECUTIVE, 139

CONTROL COMMANDS, 139

C. POSTSCRIPT LIMITS, 141

D. ERROR MESSAGES, 143

INDEX 


\section{PREFACE}

As with all computer hardware, the development of printing technology has come on apace in the last couple of years. Doubtless it will continue to do so. The most recent and most impressive developments in this field have been in the area of laser and LED page printers.

Now that the price of these printers is within the range of more and more people, there are more and more people who want to make the most of this affordable new technology. That's what this book is all about.

Computer technology develops at an increasingly dramatic rate, daring us to find new ways to put it to use. But as a result of the sheer speed at which the new developments become widely available, the number of people who are able to wring the last ounce of usefulness out of them is smaller and smaller.

This book is intended to help you realise more of the potential of your POSTSCRIPT printer. The power of POSTSCRIPT is limited only by your imagination. Just about any image that can be printed on paper can be produced by POSTSCRIPT.

Many people shy away from the 'awesome' task of actually programming whatever the language. This book is not intended as a full tutorial in programming in general or POSTSCRIPT programming in particular, but it IS intended to show that even very short and simple POSTSCRIPT programs can make your printer really earn its keep.

This book contains programs which produce many different styles of text and just as many styles of graphics. It even contains programs which will expand the number of typefaces your printer can produce.

This book was originated on a POSTSCRIPT laser printer; all of the graphics are taken directly from POSTSCRIPT output and this is still only a fraction of what POSTSCRIPT can do. Now it's over to you.

My thanks must go to Max and Carl Phillips of Strange Software Limited, London, EC1, for their Grabit software which produced the POSTSCRIPT program for the 
image of the Psion Chess program on page 33. Thanks go also to Iain Janes and Philip Mattimoe of Lotus Reprographic Services Limited, London, W6, who provided plentiful advice and information on POSTSCRIPT typesetting.

This book is for my Marvel of Peru, Fiona Maclean. 